\title{
Students' learning outcomes on hydrocarbon materials through mind mapping method
}

\author{
Andriani, Nelius Harefa*, Elferida Sormin and St Fatimah Azzahra \\ ${ }^{1}$ Department of Chemistry Education, Faculty of Teacher Training and Education, Universitas Kristen \\ Indonesia, Jakarta, Indonesia \\ *Corresponding author: NH, nelius.harefa@uki.ac.id
}

DOI: 10.24114/jpkim.v13i3.29381

Article history:

Received: 10 November 2021

Revised: 21 November 2021

Accepted: 22 November 2021

Abstract: The purpose of this study was to determine the effect of the Mind Mapping learning method on student learning outcomes in class XI MIPA SMAN 1 Siberut Tengah on hydrocarbon material. The research sample amounted to 28 students, who were selected using the Purpose Sampling technique. The instrument used was a test instrument for chemistry learning outcomes, in the form of pretest and posttest which were analyzed using SPSS 22 for window to determine the results of the T-test on the Independent Sample Test. Normality test using Shapiro-Wilk test on sig. > 0.05 that is equal to 0.034 . The results of hypothesis testing using the Independent Sample Test which shows that the value of sig. (2-tailed) $0.000<0.05$, which means $\mathrm{Ha}$ is accepted. Thus, it is concluded that there is an effect of using Mind Mapping to improve student chemistry learning outcomes.

Keywords: Hydrocarbon materials, learning outcomes, mind mapping method

\section{Introduction}

The Covid-19 pandemic that hit the world directly demands creation and innovation in various sectors of human life. Especially in the education sector, the Covid-19 pandemic has stimulated teachers, students, and education stakeholders to innovate in an effort to accommodate the learning process. In essence, this pandemic has had both positive and negative impacts on the education sector. For most teachers, students, and education stakeholders, the absence of face-to-face learning in schools is one of the negative impacts of the Covid-19 pandemic. On the other hand, not accommodating face-to-face learning in schools actually stimulates creation and innovation in an effort to find the best solution to accommodate the continuity of the learning process. One of the efforts that can be done is by applying the right learning method (Silaban, 2017).

These innovations and creations are a must so that the learning process can be accommodated. These innovations are both in terms of integrating digital-based learning 
processes and through learning systems. One of the innovations that is growing along with the Covid-19 pandemic is innovation in learning media. These learning media have been widely used, especially digital integrated learning media, both in the form of learning platforms, learning management systems (LMS), and video conference-based learning media (Harefa, 2020).

Various digital platforms have been developed in an effort to facilitate the learning process, both online and blended learning. One platform that has been developed as a learning media is schoology (Sefriani \& Sepriana, 2020). This learning platform is one of the platforms that can be used in the learning process. This platform is proven to be effective in improving students' academic abilities (Setiawan \& Aden, 2020). In addition, through the use of schoology, students' critical thinking skills can be improved (Kustandi, 2017).

Another platform that can be used in the learning process is Edmodo. This platform is one platform that is very suitable for use in universities (Jamil, 2018). In addition to college, this platform is also suitable for use in secondary schools by elaborating its features so that students can be stimulated to improve their abilities. This platform can be used by teachers as a medium for doing daily tests (Susanti \& Effendi, 2020). In general, the use of this platform can stimulate the improvement of student learning outcomes (Suharti, 2021; Novira et al. 2021). Another commonly used platform is ClassDojo. This platform can accommodate an integrated learning environment (Manolev et al. 2019), so it can be used as an integrated learning media for the surrounding environment. In addition, this platform can be developed into an LMS that can be used by students and teachers in an effort to facilitate the learning process (Chiarelli et al. 2015). This platform is generally able to stimulate the improvement of students' academic abilities (Dillon et al. 2019).

In addition, another option that can be used as an online learning platform is Google Classroom. The use of this platform can increase the effectiveness of learning (Marbun \& Sinaga, 2021), through the use of which students and teachers are accommodated to carry out the learning process flexibly so that students' learning motivation can be increased (Destyana \& Surjanti, 2021). In general, students think that this platform is effective and efficient and interesting if it is integrated into the learning process (Harefa \& Sumiyati, 2020). Another platform that can be used as a supporting medium in the learning process is Moodle. This platform is one of the platforms that can accommodate video conferencebased activities (Cabero-Almenara et al. 2019), through its use, students and teachers can do virtual direct learning, recordings of the learning process can be stored on the platform to be elaborated on other occasions. Through the use of this platform, students' academic abilities can be improved (Abdulla et al. 2020), and can accommodate science learning (Kc, 2017).

The learning method must be done repeatedly so that students are not easily bored and bored if they are in class for too long. The use of the Mind Mapping learning model, directs students to better understand the material being taught. The use of the Mind Mapping model helps students to improve learning outcomes, interest in learning, and student creativity (Amin, 2018). One of the learning methods that support students is using the Mind Mapping method. Mind Mapping can help students change students' thinking patterns, all important information is easy to understand and remember from every lesson material received. Mind Mapping can be compared with city maps. As for some of the benefits of Mind Mapping, namely, providing an overall view of the core of the problem, being able to 
plan routes or make plans and choices of where we are going and where we are, collecting data or information in one place, solving problems, fun to look at, read, and remember.

Mind mapping is one of the learning methods that can be used to improve student learning outcomes. this method can be implemented in various fields of learning studies such as social and scientific fields. This method is effective in improving student social studies learning outcomes in junior high schools. In addition to learning outcomes, the use of mind mapping can also improve students' abilities and skills in the affective and psychomotor domains. The implementation of the mind mapping method in the learning process can improve the creative thinking skills of elementary school students (Ananda, 2019). In fact, the use of the Mind Mapping method in the learning process is used to see students' abilities and students' creativity in starting a material with their creative ideas. Mind Mapping is also able to improve student achievement at school.

Learning facilities are also very influential in the learning process taking place to support the student learning process (Rahman et al. 2020) and also to support teaching activities to foster student interest and pay attention to each student when the teacher delivers material before class activities begin (Namira et al. 2020). With complete facilities, students will also be interested and more enthusiastic about participating in the learning process, and the comfort and cleanliness of the classroom will also affect the learning process in the classroom. Teachers and students must work together so that the teaching and learning process is not disturbed.

The development of technology, information, and communication has stimulated the creation of digitally integrated innovations (Silaban, 2021). In the learning process, many of these innovations have been implemented. The implementation of these platforms generally has a positive impact on the learning process. Various digital skills and abilities can be stimulated with the help of these platforms, and new skills can be developed by students and teachers. Nevertheless, the use of this digital platform must be balanced with the delivery of material and pay attention to learning outcomes.

\section{Methods}

This research is a descriptive quantitative research with a one-group pretest-posttest research design. Pre-experiment is the use of methods and procedures to make observations in a study that is structured similar to an experiment, but the conditions or experience of participation lack control because it is limited to random assignments, including comparisons or control groups (William \& Hita, 2019). The pre-experiment used in this research is Pre-experiment: One Group Pretest and Posttest Design which is a quasiexperiment where a group is measured and observed before and after treatment.

The population in this study were high school students of Class XI MIPA. The research sample was 28 IPA class XI. The sample was selected by using purposive sampling technique. Data collection method is a method or technique used by researchers to obtain and collect as much data or information as possible and the most relevant way to the problem raised and can be accounted for for the data (Crowe \& Sheppard, 2012). There are several ways to collect data: observation, documentation and test. After data collection, instrument validation techniques were carried out to analyze the level of reliability. By testing the construct validation, the opinions of experts are tested. After the expert construct testing 
was completed, the instrument trial was continued. The approved instrument was tested on a sample of the population taken. Data analysis technique Hypothesis test using T-test with the help of SPSS 22. n-gain test to determine the increase in the n-gain test.

\section{Results and Discussion}

Based on the results of research conducted at SMA Negeri 1 Siberut Tengah, Mentawai Islands Regency, there are significant differences in the results of the initial test before the implementation of the Mind Mapping learning method and after. Student pretest data as shown in Table 1. Based on Table 1, the highest value is 40 and the lowest value is 10, with a range of values of 30 . The length of the interval value is 10 , and the interval is taken 4 times. In addition to the pretest scores, the study also analyzed the students' posttest scores as shown in Table 2.

Table 1

Frequency Distribution of Student Pre-test Scores

\begin{tabular}{c|c|c}
\hline Interval Class & Frequency & \multirow{2}{*}{ Mean } \\
\cline { 1 - 2 } $0-10$ & 1 & \multirow{2}{*}{28.92} \\
\hline $11-20$ & 2 & \\
\hline $21-30$ & 17 & \\
\hline $31-40$ & 8 &
\end{tabular}

Table 2

Frequency Distribution of Student Post-test Scores

\begin{tabular}{c|c|c}
\hline Interval Class & Frequency & \multirow{2}{*}{ Mean } \\
\hline $60-70$ & - & \\
& 22 & \multirow{2}{*}{78.64} \\
\hline $81-90$ & 6 & \\
\hline $91-100$ & - & \\
\hline
\end{tabular}

Based on Table 2, the highest value is 85 and the lowest value is 75 , with a range of values of 30. After the pretest and posttest scores are known, the increase in student learning outcomes is analyzed by testing the research hypothesis as shown in Table 3.

Hypothesis testing was carried out using student posttest score data assisted by SPSS 22 for window. Hypothesis testing was carried out through 2-Independent Sample nonparametric statistical tests, this was because the pretest value data were not normally distributed. The test criteria, if the Asymp value. Sig. (2-tailed) $>0.05$ means that there is no difference in learning with the Mind Mapping method in other words Ho is accepted, and if the value of sig. (2-tailed) $<0.05$ means that there is a difference or $\mathrm{Ha}$ is accepted which is 0.000 , thus there is an increase in student chemistry learning outcomes assisted by mind mapping on hydrocarbon material.

Mind mapping assisted learning is learning that is very appropriate to use on theoretical materials which are essentially rote (Liu et al. 2014). This learning method can help students classify learning material, and make it in a simple form that is easier to understand. With the mind mapping method, students will more easily determine the relationship between 
materials and be able to identify the relationship between each of these materials (Crowe \& Sheppard, 2012).

Table 3

Hypothesis Test

\begin{tabular}{|c|c|c|c|c|c|c|}
\hline \multicolumn{7}{|c|}{ One-Sample Test } \\
\hline & \multicolumn{6}{|c|}{ Test Value $=0$} \\
\hline & \multirow[t]{2}{*}{$\mathrm{t}$} & \multirow[t]{2}{*}{$\mathrm{df}$} & \multirow{2}{*}{$\begin{array}{l}\text { Sig. (2- } \\
\text { tailed) }\end{array}$} & \multirow{2}{*}{$\begin{array}{c}\text { Mean } \\
\text { difference }\end{array}$} & \multicolumn{2}{|c|}{$\begin{array}{l}95 \% \text { confidence interva } \\
\text { of the difference }\end{array}$} \\
\hline & & & & & Lower & Upper \\
\hline Post-test result & 148.359 & 27 & .000 & 78.643 & 77.56 & 79.73 \\
\hline
\end{tabular}

The implementation of the mind mapping method generally can improve students' basic skills, one of which is writing skills. The mind mapping method that guides students to classify learning materials can automatically improve students' skills in rewriting the material (Basri \& Syamsia, 2020; Uysal \& Sidekli, 2020). Writing skills and writing demands in implementing the mind mapping method can simultaneously improve students' memory of learning materials (Annisa et al. 2018). Increasing students' memory of learning materials, can improve student learning outcomes (Bawaneh, 2019; Hapidin et al. 2019).

In addition to improving skills in the cognitive aspect, the implementation of the mind mapping method can improve other skills such as affective aspects, psychomotor aspects, and science process skills. The implementation of the mind mapping method can increase students' creativity and understanding of concepts (Taadi et al. 2019). In addition, the implementation of the mind mapping method can increase students' interest in learning in understanding a learning material (Astawa, 2019). In the higher category, the implementation of the mind mapping method can improve students' skills in analyzing a learning material (Dewantara, 2019). The improvement of skills in affective, psychomotor, and science process skills can stimulate the improvement of student learning outcomes.

\section{Conclusion}

The implementation of the Mind Mapping method can improve student learning outcomes and obtain maximum results in chemistry subjects with Hydrocarbon material. The success of learning by using the Mind Mapping learning strategy by referring to the observations that the researchers have done and getting the results that there is an increase in student learning outcomes towards Mind Mapping learning that is applied during the research process.

\section{References}

Abdula, A. I., Baluta, H. A., Kozachenko, N. P., \& Kassim, D. A. (2020). Peculiarities of using of the Moodle test tools in philosophy teaching. CEUR Workshop Proceedings 2643 306-320.

Amin, E. V., Andayani, Y., \& Sukib, S. (2018). Hubungan antara minat belajar dan kebiasaan belajar terhadap hasil belajar kimia siswa kelas XI IPA. Chemistry Education Practice, 1(1), 13-19. 
Ananda, R. (2019). Penerapan Metode Mind Mapping untuk Meningkatkan Kemampuan Berpikir Kreatif Siswa Sekolah Dasar. Edukatif: Jurnal Ilmu Pendidikan, 1(1), 1-10. DOI:10.31004/edukatif.v111.1

Annisa, R., Subali, B., \& Heryanto, W. P. (2018). Peningkatan daya ingat dan hasil belajar siswa dengan mind mapping method pada materi listrik dinamis. JP (Jurnal Pendidikan): Teori dan Praktik, 3(1), 19-23. DOI:10.26740/jp.v3n1.p19-23

Astawa, D. N. W. (2019). Influence of mind mapping method implementation on learning results social science is required from students interest. International Research Journal of Management, IT and Social Sciences, 6(3), 94-100. DOl:10.21744/irjmis.v6n3.637

Basri, N., \& Syamsia, S. (2020). The effect of applying mind mapping method in writing descriptive text. LANGUA: Journal of Linguistics, Literature, and Language Education, 3(2), 36-56. DOI:10.5281/zenodo.4087103

Bawaneh, A. K. (2019). The effectiveness of using mind mapping on tenth grade students' immediate achievement and retention of electric energy concepts. Journal of Turkish Science Education, 16(1), 123-138. DOI:10.12973/tused.10270a

Cabero-Almenara, J., Arancibia, M., \& Del Prete, A. (2019). Technical and didactic knowledge of the Moodle LMS in higher education. Beyond functional use. Journal of New Approaches in Educational Research, 8(1), 25-33. DOI:10.7821/naer.2019.1.327

Chiarelli, M., Szabo, S., \& Williams, S. (2015). Using class dojo to help with classroom management during guided reading. Texas Journal of Literacy Education, 3(2), 81-88.

Crowe, M., \& Sheppard, L. (2012). Mind mapping research methods. Quality \& Quantity, 46(5), 1493-1504. DOI:10.1007/s11135-011-9463-8

Destyana, V. A., \& Surjanti, J. (2021). Efektivitas penggunaan google classroom dan motivasi belajar terhadap hasil belajar peserta didik pada mata pelajaran ekonomi. Edukatif: Jurnal Ilmu Pendidikan, 3(3), 1000-1009. DOI:10.31004/edukatif.v3i3.507

Dewantara, D. (2019). The effect of learning with the mindmapping method using imindmap towards student's analytical ability. Indonesian Journal of Science and Education, 3(1), 1014. DOI:10.31002/ijose.v3i1.1171

Dillon, M. B. M., Radley, K. C., Tingstrom, D. H., Dart, E. H., \& Barry, C. T. (2019). The effects of tootling via ClassDojo on student behavior in elementary classrooms. School Psychology Review, 48(1), 18-30. DOI:10.17105/SPR-2017-0090.V48-1

Hapidin, H., Pujianti, Y., \& Juniasih, I. (2019). The effectiveness of using mind mapping method to improve child development assessment. Jurnal Pendidikan Usia Dini, 13(1), 172186. DOI:10.21009/10.21009/JPUD.131.13

Harefa, N. (2020). Learning management system aplikasi E-Learning untuk pembelajaran online dan blended.

Harefa, N., \& Sumiyati, S. (2020). Persepsi siswa terhadap google classroom sebagai LMS pada masa pandemi covid-19. Science Education and Application Journal, 2(2), 88-100. DOI:10.30736/seaj.v2i2.270

Jamil, N. (2018). Efektifitas edmodo sebagai media pembelajaran di perguruan tinggi. CBIS, 6(1), 40-7. DOI:10.33884/cbis.v611.577

Kc, D. (2017). Evaluation of moodle features at kajaani university of applied sciences-case study. Procedia computer science, 116, 121-128. DOI:10.1016/j.procs.2017.10.021

Kustandi, C. (2017). Efektivitas E-Learning berbasis edmondo dan schoology terhadap kemampuan berfikir kritis mahasiwa program studi teknologi pendidikan FIP UNJ pada 
mata kuliah profesi pendidikan. Educate: Jurnal Teknologi Pendidikan, 2(1). DOI:10.32832/educate.v2i1.1034

Liu, Y., Zhao, G., Ma, G., \& Bo, Y. (2014). The effect of mind mapping on teaching and learning: A meta-analysis. Standard Journal of Education and Essay, 2(1), 17-31.

Manolev, J., Sullivan, A., \& Slee, R. (2019). The datafication of discipline: ClassDojo, surveillance and a performative classroom culture. Learning, Media and Technology, 44(1), 36-51. DOI:10.1080/17439884.2018.1558237

Marbun, J., \& Sinaga, S. J. (2021). Pemanfaatan aplikasi google classroom dalam meningkatkan efektivitas belajar mahasiswa berbasis daring di masa pandemik covid-19. Jurnal Basicedu, 5(5), 3299-3305. DOI:10.31004/basicedu.v5i5.1326

Namira, F., Azura, W., Miranda, A., Nisa, H., Silaban, S., Suyanti, R. D., \& Darmana, A. (2020). Analysis of constraints and innovation of chemistry experiment implementation in high school in Deli Serdang, Indonesia. Jurnal Pendidikan Kimia, 12(3), 106-115. DOI:10.24114/jpkim.v12i3.21159

Novira, P., Silalahi, A., \& Silaban, S. (2021). Analysis effectiveness of the online learning through the use of google classroom during the Covid-19 pandemic. Jurnal Pendidikan dan Pembelajaran Kimia, 10(1), 88-93.

Rahman, G., Nasution, R. F., Lubis, A. R., Novira, P., Rahman, L., Sinaga, E. H. R., ... \& Silaban, S. (2020). Analysis of constraints and alternative solutions to the implementation of chemical practicums in several high schools in Medan. Jurnal Pendidikan Kimia, 12(1), 4451. DOI:10.24114/jpkim.v12i1.17744

Sefriani, R., \& Sepriana, R. (2020). Pengembangan media E-Learning berbasis schoology pada pembelajaran kurikulum pendidikan teknologi dan kejuruan. Edukatif: Jurnal Ilmu Pendidikan, 2(1), 9-14. DOI:10.31004/edukatif.v2i1.76

Setiawan, T. H., \& Aden, A. (2020). Efektifitas penerapan blended learning dalam upaya meningkatkan kemampuan akademik mahasiswa melalui jejaring schoology di masa pandemi covid-19. JPMI (Jurnal Pembelajaran Matematika Inovatif), 3(5), 493-506. DOI:10.22460/jpmi.v3i5.p\%25p

Silaban, S. (2017). Dasar-dasar pendidikan matematika dan ilmu pengetahuan alam. Medan: Harapan Cerdas Publisher.

Silaban, S. (2021). Pengembangan program pengajaran. Medan: Yayasan Kita Menulis.

Suharti, S. (2021). Efektivitas penerapan media pembelajaran interaktif berbasis edmodo dalam menyongsong era revolusi industri 4.0 terhadap hasil belajar matematika siswa. Jurnal Cendekia: Jurnal Pendidikan Matematika, 5(2), 1025-1038. DOI:10.31004/cendekia.v5i2.564

Susanti, R. D., \& Effendi, M. (2020). Efektivitas penggunaan edmodo dalam pelaksanaan ulangan harian matematika. FIBONACCI: Jurnal Pendidikan Matematika dan Matematika, 6(1), 9-16. DOI:10.24853/fbc.6.1.9-16

Taadi, D., Raharjo, T. J., \& Deliana, S. M. (2019). The effect of mind mapping based imindmap application on the creativity and concept understanding of students. Innovative Journal of Curriculum and Educational Technology, 8(1), 41-50. DOI:10.15294/IJCET.V8I1.31337

Uysal, H., \& Sidekli, S. (2020). Developing story writing skills with fourth grade students' mind mapping method. Egitim ve Bilim, 45(204). DOI:10.15390/EB.2020.8848 